\title{
Ryszarda Cierzniewska
}

Uniwersytet Kazimierza Wielkiego w Bydgoszczy

\section{Doktoranci w szczelinach akademickości}

\section{Wprowadzenie}

Wprowadzenie trzeciego segmentu kształcenia wyższego na mocy tak zwanych ustaleń Deklaracji Bolońskiej (2003) i Strategii Lizbońskiej (2005) zmieniło fundamentalnie całokształt życia akademickiego, choć nie wszystkie aspekty tej rewolucji były i sa widoczne. Niektóre odkrywane sa stopniowo, a wiele skutków uwidoczni się z cała ostrościa w kolejnych latach. Maria Czerepaniak-Walczak analizujacc to zjawisko, wskazuje na następujące źródła problemów, które budzą niepokój środowiska uczonych, a mianowicie na:

a) „tradycję, a zwłaszcza napięcie wywołane różnicami między tradycyjnymi formami przygotowania do kariery badawczej, zwiazanej głównie $z$ kariera akademicka, a nowymi koncepcjami w tym zakresie;

b) nadmiar regulacji prawnych towarzyszacych wdrażaniu nowych form kształcenia młodych badaczy;

c) lęk przed „drenażem mózgów” zarówno w skali kraju, jak i Europy (a także w skali globalnej)"'.

Każde ze wskazanych źródeł niepokojów wymaga zastanowienia, odczytania w narracjach uczestników "gry naukowej” i próby negocjacji, gdyż jak wskazują badania, staja się one prawdą obiegowa, oczywistościa głęboko zapadająca w mentalność zbiorowa społeczności uczonych. Czerepaniak-Walczak, jak odczytuję jej słowa, podejmuje próbę szerokiego spojrzenia na fenomen studiów doktoranckich (choć głównie odnosi się

${ }^{1}$ M. Czerepaniak-Walczak, Studia doktoranckie $w$ systemie szkolnictwa wyższego $i$ społeczeństwie wiedzy: komu i do czego potrzebne sa studia doktoranckie na kierunku/ dyscyplinie pedagogika, „Rocznik Pedagogiczny” 2013, nr 36, s. 70. 
do akademickiego środowiska pedagogów) z wyraźnie określonej perspektywy „społeczeństwa wiedzy”. W moim badawczym oglądzie zostanie podjęta próba zidentyfikowania tego, co zachodzi w głębi instytucjonalnych i jednostkowych doświadczeń uczonych. Według mnie, do wskazanych źródeł niepokoju należy również dołączyć kwestie, które ostatnio angażują opinię publiczna, czyli oczekiwań „społecznych” wobec absolwentów studiów doktoranckich oraz kwestie potrzeb samych doktorantów.

Metafora szczeliny została użyta dla podkreślenia stanu, w jakim się znaleźli studenci studiów trzeciego stopnia po reformie szkolnictwa wyższego. Szczelina kojarzy się z geologicznym rozstępem powstającym w wyniku silnych działań sejsmicznych, czy też klimatycznych. Jest zatem pęknięciem powłoki ziemi, rysa, która w wyniku dalszych zjawisk kresowych bądź zjawisk sejsmicznych powiększa się, pogłębia, tworząc nowe ukształtowanie powierzchni, czasami sięgając głębszych warstw skorupy ziemskiej (co zależy od przyczyn jej powstawania), może być symptomem ruchu płyt sejsmicznych. Szczelina nigdy nie powstaje bez powodu, a przyczyny jej powstawania sa zazwyczaj niezwykle silne i maja wręcz dramatyczny przebieg dla życia na ziemi. Znaczacy jest również fakt, że jest trwała zmiana, często pogłębiająca się i zawsze majacca znaczenie dla ekosystemu. To, co dostaje się do szczeliny, może ją cementować, wiązać lub rozsadzać. Moga w niej powstawać specyficzne warunki życia korzystne dla pewnych gatunków roślin i zwierząt, a gromadzący się materiał geologiczny, w postaci głazów, kamieni i piasku, czy też wdzierająca się woda moga pogłębiać i poszerzać rozmiary pęknięcia.

Gdyby przyjąc przez analogię, że dla nauki i uczonych ziemią, wraz $z$ jej wszelka różnorodnościa, jest akademia, universitas $z$ wytworzona przez wieki kultura bycia uczonym, to można znaleźć uzasadnienie dla przyjętej metafory. Prowadzone przeze mnie od 2005 roku badania dotyczace przemian zachodzacych w akademickim środowisku pedagogów skłaniaja do konkluzji, że tych szczelin o różnych rozmiarach i zawartości w przestrzeni akademickiej jest wiele. Każda wypełniona jest nieco innym „materiałem”, a okolicznościom powstania można nadawać inne znaczenia, jednak zawsze skutki przynoszą bliższą lub dalszą zmianę, na która warto się przygotować. Druga konstatacja wprowadza dopełnienie sformułowania zawartego w tytule. Otóż w owej metaforycznej szczelinie/szczelinach znajdują się wszyscy zajmujący się nauką, a przy pogłę- 
bianiu się jej/ich do rozmiarów ogromnego krateru skutki już sa/i będa coraz bardziej odczuwalne dla szerszego społeczeństwa. Podejmujac hermeneutyczny namysł o nachyleniu krytycznym, postaram się wskazać owe „szczeliny” i konsekwencje znalezienia się w nich młodych uczonych (tak będę traktowała studentów studiów doktoranckich), zastrzegajac jednak szkicowy charakter tego opisu, bowiem mała forma artykułu narzuca reguły, obligując do skondensowania prezentowanych treści. Jednocześnie pragnę dodać, że to, co prezentuję, jest pewnym fragmentem większej całości (książki W szczelinach akademickości, która przygotowuję). Przyjęty model pracy intelektualnej wpisuje się w podwójna hermeneutykę, która uczula na potrzebę czy wręcz konieczność odnoszenia konkluzji wyprowadzonych w toku nadawania znaczeń do teoretycznego zaplecza. Jak powiada Anthony Giddens, możemy w ten sposób więcej zobaczyć, a nadto poddać wyprowadzane tezy wstępnemu, bardzo subtelnemu falsyfikacjonizmowi². Gwoli ścisłości należy dodać, że mój hermeneutyczny namysł ma manierę krytyczności, poszukującej nie tylko sensów życia społecznego, ale również prowokowania do własnych interpretacji i poszukiwania możliwości zapanowania nad rzeczywistościa. W moim przekonaniu właśnie w takim ujęciu jest możliwe rozważanie fenomenu akademickości, lokowanego na poziomie integracji społecznej ${ }^{3}$ (mikrosocjologiczne wymiary), a następnie przejście na poziomy makrosocjologiczne, by w ten sposób połączyć odrębne empirycznie przedmioty badañ ${ }^{4}$.

\section{Szczeliny w akademickości}

Academia to świat uczonych, świat nauki, w którym stykają się kontekstualnie zjawiska o podłożu społecznym, politycznym i ekonomicz-

\footnotetext{
2 Tym samym sygnalizuję, że lokuję swoją orientację epistemologiczno-metodologiczna w nurcie rozważań hermeneutycznych z krytyczną wersja interpretatywną. Podwójna hermeneutyka została m.in. zdefiniowana przez A. Giddensa, Nowe zasady metody socjologicznej. Pozytywna krytyka socjologii interpretatywnych, tłum. G. Woroniecka, Zakład Wydawniczy Nomos, Kraków 2001, s. 121-137.

3 A. Giddens, Stanowienie społeczeństwa. Zarys teorii strukturacji, tłum. S. Amsterdamski, Wydawnictwo Zysk i S-ka, Poznań 2003, s. 77 i n.

4 J.C. Alexander, Znaczenia społeczne. Studia z socjologii kulturowej, tłum. S. Burdziej, J. Gądecki, Zakład Wydawniczy Nomos, Kraków 2010, s. VII, 52.
} 
nym, o zasięgu ogólnym, lokalnym i indywidualnym ${ }^{5}$. Akademickość (tu kategoria uczulająca, w połaczeniu $z$ metafora szczeliny) osadzana jest w każdym środowisku, które za swoja podstawowa aktywność przyjmuje generowanie nauki oraz kształcenie studentów. Warto w tym miejscu przypomnieć, że już Humboldt wskazał trzy zasady, organizujące i charakteryzujace życie naukowe w uniwersytecie: samotność, wolność i współpracę społeczności uczonych ${ }^{6}$. Akademickość rozumiem również jako instytucjonalne uprawnienia jednostek naukowych do realizacji procedur awansów naukowych, połaczone $z$ moralnym zobowiązaniem uczonych do przestrzegania kanonu zasad uprawiania nauki i generowania kolejnych pokoleń uczonych dla zachowania jej ciagłości, co u Mertona zostało skodyfikowane w trzech zasadach: komunizmie, bezinteresowności i zorganizowanym sceptycyzmie ${ }^{7}$. Wspomnę jeszcze o znaczacym dla prowadzonych dalej rozważań fakcie, że na straży etosu - tu akademickości - stali uczeni, którzy byli zobowiązani do reagowania na zaburzenia w respektowaniu kanonu moralnego nauki, publicznej krytyki dotyczacej patologii naruszających dobra praktykę wewnatrz środowiska oraz dostrzeganych zagrożeniach płynacych $z$ zewnatrz ${ }^{8}$.

Akademickość była również wyznacznikiem specyficznej kultury intelektualnej i kodeksu postępowania zwanego etosem nauki, do niedawna niespisanym zbiorem norm aksjologicznie uzasadnionych reguł funkcjonowania ludzi nauki. Jak twierdziła Maria Ossowska, ów kodeks ustanowiony konsensualnie regulował nie tylko aktywność zawodowa, ale był swoistym stylem życia, maniera zinterioryzowana w osobie uczonego ${ }^{9}$. Cechą konstytutywna dla środowiska akademii był i jest jej hierarchiczny porzadek, naturalny i wręcz nieodzowny dla zachowania ciąłłości

${ }^{5}$ Zob. R. Cierzniewska, Wokół przemian akademickiego środowiska pedagogów w Polsce, Wydawnictwo UKW w Bydgoszczy, Bydgoszcz 2011. Pewne fragmenty tekstu zostały zaczerpnięte $z$ przywołanej książki, jednak tu zinterpretowane pod kątem celów określonych $\mathrm{w}$ niniejszym opracowaniu.

${ }^{6}$ K. Sauerland, Idea uniwersytetu: aktualność tradycji Humboldta?, „Przegląd Pedagogiczny" 2008, nr 1, s. 31.

7 R.K. Merton, Teoria socjologiczna i struktura społeczna, tłum. E. Morawska, J. Wertenstein-Żuławski, Wydawnictwo Naukowe PWN, Warszawa 2002, s. 583-591.

8 J. Goćkowski, Uniwersytet i tradycja w nauce, Wydawnictwo „Secesja”, Kraków 1999, s. 88 .

9 M. Ossowska, Podstawy nauki o moralności, Wydawnictwo Naukowe PWN, Warszawa 1966 , s. 256-257. 
pokoleniowej oraz utrzymania progresu nauki, co regulowały wewnętrzne, etosowe prawa ${ }^{10}$. Dziś ten układ jest kwestionowany (tu identyfikuję pierwszą szczelinę, w której znalazł się świat uczonych), z różnych powodów uznaje się jego archaiczność, kwestionuje zasadność utrzymania rozbudowanej struktury (chodzi o rezygnację $z$ przyznawanych dożywotnio stopni i tytułów doktora habilitowanego i profesora), na rzecz spłaszczonej, odwołującej się nie do autorytetu nauki i pozycji uczonego, ale do pełnionej $\mathrm{w}$ danym momencie roli kierowniczej $\mathrm{w}$ prowadzonym projekcie naukowym (stanowisko, nie tytuł profesora). Pierwsza wattpliwość, która się pojawia, jest zwiąana $z$ tym, dlaczego nie kwestionuje się rozbudowanych szczebli kształcenia, wręcz dodano, na mocy ustaleń bolońskich, stopień licencjata (zatem istnieje potrzeba różnicowania poziomu kompetencji). Drugie zastrzeżenie dotyczy ról pełnionych wobec nauki i społeczeństwa przez osoby znajdujące się na różnych szczeblach kariery naukowej. Do tego watku powrócę w dalszej części moich interpretacji.

Na straży etosu stali uczeni przyjmujacy role „aktorów w przestrzeni akademickiej", w która wpisana była odpowiedzialność za jakość pracy intelektualnej, a międzypokoleniowe zobowiązania dotyczyły kultywowania swoistej ideologii, moralności uczonych, przygotowania teoretycznego i metodologicznego zgodnie z regułami spisanymi przez Janusza Goćkowskiego: historycyzmu (ciagłości kulturowej), uniwersalizmu (wolności naukowej majacej tylko ograniczenia moralne i merytoryczne), autotelizmu (najwyższej wartości, która stanowi rozwój własnej dyscypliny), kooperacjonizmu (powinności wspólnotowego interpretowania i konsumowania efektów) ${ }^{11}$. Już w tym miejscu widoczna jest kolejna szczelina, w której znalazł się świat akademii. Dotychczas głównym celem była dbałość o rozwój własnej dyscypliny naukowej, tym czasem w roszczeniach dziś kierowanych do uczonych zauważalny jest wyraźny zwrot w kierunku praktycznych zastosowań, co oczywiście nie wyklucza rozwoju nauki, wręcz dynamizujac jej przyrost w pewnych zakresach. Jednak rozwiązywanie pragmatycznych problemów wymaga innego podejścia, sięgania

10 Zob. L. Fleck, Psychosocjologia poznania naukowego, Wydawnictwo Uniwersytetu Marii Curie-Skłodowskiej, Lublin 2006; F. Znaniecki, Społeczne role uczonych, wstęp, przekład tekstów angielskich i red. nauk. J. Szacki, Wydawnictwo Naukowe PWN, Warszawa 1984.

11 J. Goćkowski, op.cit., s. 94-96. 
do interdyscyplinarnego zaplecza, często odległych teorii ulokowanych w różnych gałęziach nauki. Nadto praca zadaniowa charakteryzuje się elastycznym przechodzeniem od jednego problemu do następnego, co stawia świat akademii w zgoła innych warunkach naukowego działania. Wspólnota uczonych dotychczas skupiona na rozwoju swojej dyscypliny staje się płynną konstrukcja tworzona na zamówienie, pod projekt. Więzi między uczonymi, które niegdyś stanowiły rusztowanie dla budowania kultury etosowej, stopniowo zamieniaja się w kruche relacje o charakterze strategicznym, a ich płynność zwalnia z głębszych zobowiązań wobec środowiska. Tę szczelinę pogłębiają kolejne, coraz bardziej restrykcyjne regulacje resortowe, przy jednoczesnym uszczuplaniu środków przeznaczanych na szkolnictwo wyższe i naukę. Podsycany motyw rywalizacji o fundusze na badania, o zachowanie własnego bezpieczeństwa egzystencjalnego - utrzymanie zatrudnienia bądź w ogóle uzyskanie w miarę stałej posady w uniwersytecie lub jednostce badawczej, dziś to stałe komponenty akademickiej pracy. W ten oto sposób dotychczasowe podziały wynikające $z$ różnic merytorycznych nie tracąc na znaczeniu (interdyscyplinarność), łączą się z konkurowaniem o bazę ekonomiczną. Świat akademii staje się arena bezwzględnej rywalizacji ukierunkowanej na cele określane przez instytucje zatrudniające uczonych, zewnętrzne podmioty zlecajace problemy do rozwiazania. Pracownik naukowy wprawdzie odkrywa i nadal opisuje świat, jednak jego kreatywność i potencjał intelektualny zostały okiełznane przez zleceniodawców. Jaskrawą egzemplifikacja tego zjawiska jest kierowanie środków publicznych, w tym unijnych, na badania naukowe do przedsiębiorców, którzy moga aplikować o tak zwane środki celowe przeznaczone na wygenerowanie nowych lub udoskonalenie istniejacych produktów przemysłowych, procesów lub usług. Beneficjentami tych funduszy moga być również podmioty społeczne, zamawiajace ekspertyzy świadczenia usług dla ludności, w tym administracja lokalna i urzędy pracy ${ }^{12}$. Akademickość i etosowe normy poszukiwania wiedzy dla niej samej siła regulacji ministerialnych stopniowo przekształcaja się w think tanki, czyli systemy eksperckie. Zarządzanie strukturami akademickimi powinno być zbli-

12 Potrzebujemy strategii. Rozmowa $z$ prof. Lena Kolarską-Bobińska, Minister Nauki i Szkolnictwa Wyższego, „Forum Akademickie” 2014, nr 2, https://forumakademickie.pl/ fa/2014/02/potrzebujemy-strategii/ (dostęp 12.10.2015). 
żone do sprawnego nadzoru stosowanego w instytucjach bankowych ${ }^{13}$. Mowa tu o wprowadzeniu w akademickie instytucje logiki korporacyjnej opartej na zarządzaniu „zasobami ludzkimi”, przekuwaniu efektów pracy uczonych w ekonomiczny zysk.

Konsekwencje tych przemian dla świata uczonych opiszę, odwołujac się do tez postawionych przez Richarda Sennetta, który sam siebie określa jako pragmatystę, badajacego zmiany zachodzace w stosunkach pracy i wynikajace $z$ nich skutki ${ }^{14}$. Konsultanci/eksperci od zarządzania, będacy osobami spoza środowiska uczonych, maja za zadanie wprowadzanie mechanizmów zapewniających efektywność pracy środowiska. $Z$ dystansem do kwestii etosowych maja wdrażać procedury przekształcajace peryferia instytucji (w centrum jest władza), wymuszać zwolnienia, zamykanie całych działów i stawiać zadania przed tymi pracownikami, którzy moga przetrwać ten proces. „Bolesny” obowiąek jest możliwy do wypełnienia, gdyż jak twierdzi Sennett, zewnętrzni eksperci nie musza poczuwać się „do większej odpowiedzialności zarówno za sposób wprowadzanych decyzji, jak i za ich konsekwencje dla ludzi”. Jest wiele przykładów wadliwych projektów oraz szkód wyrządzonych organizacji i osobom w niej zatrudnionym, jednak ekspert odchodzi, nie ponoszac $z$ tego tytułu konsekwencji. Dalej autor tych słów stawia zasadnicze pytanie, jaka korzyść ma kierownictwo z ich zatrudniania? Stwierdza, że „już sama ich obecność stanowi wyraźny sygnał ideologiczny, że władza jest egzekwowana [...], a kierownicy moga oddalić od siebie odpowiedzialność za bolesne decyzje"15. W toku prowadzonych badań wielokrotnie dziekani wydziałów, choć polemiczni wobec odgórnych decyzji ministerialnych, wdrażali kolejne przepisy, procedury, podporzadkowujac funkcjonowanie jednostek obowiązującym regułom. Eksperci ministerialni (na poziomie unijnym i państwowym) opracowywali kolejne przepisy, które zmieniały żywy organizm akademii, zmierzając do unifikacji systemów lokalnych. Wszystko to działo się ponad głowami ludzi, ponad kultura lokalną, w imię efektywności i opłacalności, ale czyjej?

\section{Ibidem.}

${ }^{14}$ R. Sennett, Etyka dobrej roboty, tłum J. Dzierzgowski, Warszawskie Wydawnictwo Literackie MUZA SA, Warszawa 2010, s. 351.

15 R. Sennett, Kultura nowego kapitalizmu, tłum. G. Brzozowski, K. Osłowski, Warszawskie Wydawnictwo Literackie MUZA SA, Warszawa 2010, s. 46-48. 
Biurokratyczne zarządzanie wywołuje trzy deficyty społeczne, na co uczula dalej Sennett i w moim przekonaniu wszystkie rozsadzaja akademicką wspólnotowość, tworząc kolejne szczeliny, w których tkwia wszyscy - od studentów poczynając, na kadrze naukowej kończąc.

Po pierwsze, obniża się poczucie lojalności wobec instytucji, co przekłada się na jakość pracy i zaangażowanie w cele przez nią realizowane. Zatem w przypadku instytucji akademickich może znaczaco przyczynić się do jakości edukacji (w tym na studiach doktoranckich) i dynamiki rozwoju nauki. Działania aktorów społecznych moga być obliczone na miarę „skrojonych" formalnie i ekonomicznie oczekiwań (punkty zapewniające stypendia, stwarzajace dogodne warunki do ubiegania się o granty badawcze; dydaktyka sformatowana do preferowanych kompetencji itp.). Pojawia się tu zjawisko zidentyfikowane przez Niklasa Luhmanna, który stwierdził, że w takich okolicznościach pojawiają się zachowania obronne, ludzie reguluja swoja sytuację przez „podwójną kontyngencje”. Zachowuja się w taki sposób, w jaki są traktowani, przystosowują się z uwagi na własne strategiczne interesy ${ }^{16}$. To musi wywoływać patologiczne zachowania nielicujace $z$ akademickimi wartościami. Niebezpieczeństwo tkwi również w tym, że systemy społeczne sa systemami „autopojetycznymi", czyli samoodtwarzajacymi się, samoreferencyjnymi, zatem taki styl zachowania wchodzi w miękka tkankę kultury środowiska akademickiego. Odchodzenie od norm etosowych na rzecz instytucjonalnych regulacji staje się oczywistą reguła, co moga potwierdzać reakcję różnych grup interesu. Presja dla takiego działania została jednoznacznie sformułowana przez samych doktorantów, oczekujacych zdyscyplinowania samodzielnych pracowników nauki ${ }^{17}$. Brak w uzasadnieniach odniesień do innych przyczyn mogacych wpłynąć na jakość realizowanych studiów doktoranckich stawia w opozycji adeptów nauki i ich mistrzów, co musi budzić zastanowienie. Wspomniałam wcześniej, że w akademickość tradycyjnie pojmowana wpisana była hierarchiczność środowiska uczonych, a tym czasem mamy zgoła inny układ. Jest usługobiorca domagajacy się

16 N. Luhmann, Essays on Self-Reference, Columbia University Press, New York 1990, s. 21-85, za: P. Baert, F.C. da Silva, Teorie społeczne $w$ XX wieku i dzisiaj, przekł. S. Burdziej, Dom Wydawniczy Nomos, Kraków 2013, s. 79.

17 Zob. Diagnoza stanu studiów doktoranckich 1.0. Krajowa Reprezentacja Doktorantów, Warszawa 2014, www.krd.org.pl (dostęp 12.10.2015). 
respektowania swoich potrzeb i usługodawca, którego należy zdyscyplinować, okiełznać przepisami, procedurami, aby właściwie wypełnił swoje zadanie. System regulacji przejmuje kontrolę nad systemem społecznym, zatem należy oczekiwać, że kolejne pokolenia uczonych, w naturalny sposób absorbujące logikę instytucjonalnego funkcjonowania, właśnie w taki sposób będą odgrywać swoją zawodową rolę (autopojetycznosć).

Po drugie, więzi między pracownikami znacznie się osłabiają, natomiast we współpracy pojawia się silny element konkurencji, co powoduje destrukcję na poziomie zaufania formalnego i nieformalnego. Presja płynności zatrudnienia, krótkotrwałych kontraktów, przechodzenie od jednego zespołu badawczego do kolejnego, stała kontrola i rozliczalność degraduja obydwa poziomy ufności pracowniczej. Sieci powiązań międzyludzkich przyjmuja charakter interesowny, szybkie i pozaosobowe kontakty, przekazywanie droga mailowa informacji i poleceń, dystansuja władzę wobec podwładnych oraz współpracowników między sobą. Brakuje czasu, energii i zaufania do budowania wspólnoty myśli, a zatomizowany świat akademii dzieli się na coraz drobniejsze kawałki. Jak twierdzi Sennett:

[...] niski poziom nieformalnego zaufania nie jest zwykłym problemem jednostek, lecz deficytem organizacji. [...] Przedsiębiorstwa te, mimo całego nacisku na zewnętrzne aspekty kooperacji, sa bardziej odczłowieczone i nieprzejrzyste od instytucji, w których ludzie robią długoterminowe kariery wśród dobrze znanych współpracowników ${ }^{18}$.

Tymczasem w systemie europejskiej nauki, w którym tkwia polskie uczelnie, dynamicznie wprowadza się regulacje służące zewnętrznemu sterowaniu efektywnościa, w imię poprawy jakości edukacji wyższej ${ }^{19}$.

Po trzecie, obniżenie potencjału wiedzy, która dysponuje instytucja i ludzie w niej zatrudnieni. W tradycyjnie pojmowanej akademickości były jasno określone cele, a wspólnota uczonych połaczona moralnie uzasadnionymi powinnościami. Gdy sieci powiązań społecznych sa kruche, niezobowiązujące, pojawia się niechęć do dzielenia się wiedzą. Tu należy podkreślić, że prowadzenie zajęć na studiach doktoranckich jest/może

18 Ibidem, s. 55-56.

19 Zob. A. Kraśniewski, M. Próchnicka, Benchmarking procesu wdrażania Krajowych Ram Kwalifikacji w polskich uczelniach, Fundacja Rektorów Polskich, Warszawa 2013. 
być dla wielu uczonych wyzwaniem moralnym. Dzielenie się swoim doświadczeniem, wiedza, badaniami i zwiąanymi $z$ nimi problemami z „własnym” doktorantem jest zgoła czymś innym, niż przekazywanie tegoż podopiecznym innych promotorów ${ }^{20}$. Administracyjne reguły dziś obowiąujące $\mathrm{w}$ akademii tylko pozoruja presje związana ze wspólnotowościa (parametryzacja jednostek naukowych), de facto zmuszając kierowników (dziekanów) do skrupulatnego rozliczania z produkcji naukowej, a dwuletnie okresy oceny ustawowo określone mają sprzyjać selekcji uczonych. Sennet i na to zwrócił uwagę - eliminacja osób kumulujących wiedzę, przez długotrwałe wykonywanie określonych, względnie stałych zadań, powoduje kurczenie się wiedzy, która jest w dyspozycji instytu$\mathrm{cji}^{21}$. Tak oto mamy wyraźna zmianę dotykająca świata akademickiego, bowiem kluczowym celem jego bycia jest kumulacja stopniowo odkrywanej wiedzy, obrabianie i konsumowanie jej we wspólnocie uczonych oraz międzypokoleniowy przekaz. Przypomnę, że wspólnota wypełniająca przestrzeń akademicka to „pole”, jak mówił Pierre Bourdieu, potencjału i ograniczeń, w nim zachodzi szczególny przekaz wartości i sztuki uprawiania nauki we współbyciu, ścieraniu się poglądów, wątpieniu i poszukiwaniu. Tego nie można się nauczyć poza nim, w przekazie słownym ani w instrukcji. Wiedza milczaca, nieuchwytna, trudna do zwerbalizowania, charakteryzująca wirtuozów, mistrzów umiera wraz z nimi, gdy nie jest przekazywana twarza $\mathrm{w}$ twarz ${ }^{22}$. Uczestniczenie $\mathrm{w}$ zmaganiach intelektualnych, przyglądanie się, jak powstaja projekty, czy tworzy się bądź falsyfikuje teorie, jest najlepszą szkoła naukowego myślenia. Dalej Bourdieu stwierdza, że młode pokolenia powinny osiagać poziom najlepszych w „polu”. Nie wolno marnować czasu, energii i talentu na samodzielne zgłębianie, odkrywanie niuansów wcześniej rozpoznanych, bowiem ma to negatywne skutki dla dynamiki rozwoju danej dyscypliny ${ }^{23}$. Tu pojawia się kolejna szczelina, w której znaleźli się uczeni, bowiem konieczna jest postawa, która wymaga choćby częściowego zawie-

\footnotetext{
${ }^{20}$ Sygnalizuję bardzo poważny problem wymagający pogłębionych badań.

${ }^{21}$ Ibidem, s. 52-59.

${ }^{22}$ R. Sennett, Etyka dobrej roboty..., s. 33 i n.

${ }^{23}$ P. Bourdieu, Specyfika dziedziny naukowej $i$ społeczne warunki rozwoju wiedzy, w: Kryzys $i$ schizma. Antyscjentystyczne tendencje $w$ socjologii współczesnej, wybór i wstęp E. Mokrzycki, Zakład Wydawniczy Nomos, Warszawa 1984, s. 89.
} 
szenia wlasnych ambicji, rezygnacji z bezwzględnego konkurowania z uczestnikami gry o naukę, na rzecz jej rozwoju, przygotowywania młodych pokoleń naukowców, a instytucjonalna, korporacyjna organizacja pracy akademickiej podważa logikę takich zachowań. Jeżeli zawierzyć słowom Pierra Bourdieu, dotyczącym przejmowania od „pola społecznego" obowiazujacych reguł życia, motywów podejmowanych wyborów, stylu myślenia i działania, a na to się nałożą określone warunki instytucjonalne, petryfikujące lub wręcz wzmagające owe zachowania, to można odczuwać poważny niepokój ${ }^{24}$.

W tym miejscu odwołam się do badań własnych, przeprowadzonych wśród doktorantów. W toku rozmów badawczych pojawił się watek współpracy, wspólnotowości, opisujący jakość relacji między młodzieżą akademicką. Okazuje się, że taką więź odczuwają w pierwszych semestrach trwania studiów doktoranckich, jednak kolejne przynosza rozluźnienie relacji. Tłumacza ten stan coraz większym obciażeniem praca zawodowa (większość pracuje na swoje utrzymanie), własnym rozwojem naukowym i przyrostem zadań związanych $z$ realizacja projektu naukowego („mam temat doktoratu, który innych nie interesuje, [...] ja również nie bardzo znam się na tym, co niektórzy robia”; "maja swojego promotora, to co ja(!)". Zatem nie lokują rozwoju we wspólnocie doktorantów, poszukujacc tego w innych gremiach naukowych. Pojawił się również wątek narastającej niechęci do współpracy i pomocy, co argumentowano różnicami paradygmatycznymi (metodologicznymi, teoretycznymi, ideologicznymi), inna problematyka badawcza czy też względami osobowymi („nie odpowiada mi ich sposób myślenia”, „są zarozumiali”, „poznałam ich i już nic ciekawego nie wniosa”, „komentuja złośliwie”).

Interpretacja materiału badawczego wykazuje ujawnianie się dwóch faz, w pierwszej doktoranci sa otwarci, chętni do współbycia i współpracy. Łaczy ich poczucie statusu wyjątkowości („jak dostałam się, byłam szczęśliwa”, „doktorant, a nie magister, których pełno”, „nawet nie marzyłam, że tak się ułoży”, „zawsze chciałem być uczonym, to dla mnie szlachectwo"), pewnego zagubienia (sygnalizowano nieznajomość reguł "gry naukowej” i ludzi w nią zaangażowanych, funkcjonowania instytucji związanych $z$ nauka). Uczony, odkrywajacy świat, to nadal jeden $z$ arche-

24 P. Bourdieu, Zmysł praktyczny, tłum. M. Falski, Wydawnictwo Uniwersytetu Jagiellońskiego, Kraków 2008, s. 73. 
typów osób wybitnych, obietnica nietuzinkowego życia, dla wybranych. Z takim „bagażem” przekonań doktoranci zaczynaja studia trzeciego stopnia, maja nadzieję na sukces naukowy i zawodowy w postaci uzyskania etatu w akademii. Akademickość w swojej tradycyjnej figurze jest symbolem szlachetności, bezinteresowności, wspólnoty trosk i nadziei w imię nauki. Początkowa radość i wielkie nadzieje skutkują optymizmem i chęcia chłonięcia wszystkiego, a pewne zagubienie wywołuje potrzeby wzajemnego wspierania się, dzielenia cennymi informacjami. Sprzyja temu również mglista wiedza o kompetencjach koleżanek i kolegów, niska świadomość układów społecznych, w których sieć jest za sprawą opiekunów naukowych właczony każdy doktorant. $Z$ biegiem czasu informacje te dopływaja, rodzi się ocena sytuacji własnej i innych, szans i trudności, jakie należy pokonać. Rozpoznane reguły instytucjonalnego uprawiania nauki, logika konkurencyjności, walki o każdy punkt do oceny, zmniejszające się szanse na uzyskanie zatrudnienia i wzrastajacy dystans wraz z powierzchownością relacji między doktorantami charakteryzują druga fazę bycia młodym uczonym/doktorantem. To mogą być czynniki, które atomizują tę kruchą wspólnotę młodych uczonych i charakteryzują społeczność doktorantów w drugiej połowie studiów doktoranckich. Z pierwszej fazy, która nazwałam etapem nadziei ulokowanych w tradycji akademickiej, młodzi ludzie przechodza w druga o znamionach rozczarowania i kryzysu, która pojawia się pod koniec drugiego roku studiów ${ }^{25}$. Akademickości we współcześnie istniejacych ramach już się przyjrzeli $z$ bliska, wspólnota doktorantów stopniowo ochładza się, każdy idzie w inną stronę, szukając w tym siebie i swojego miejsca. Większość z moich rozmówców po drugim roku choć jeszcze miało nadzieję na uprawianie nauki przez całe życie, to jednak towarzyszyła im świadomość, że w uniwersytecie szanse na zatrudnienie maja niewielkie. Tylko jedna osoba stwierdziła, że chce i „będzie to robić, nawet utrzymując się $z$ pracy na przysłowiowym zmywaku”, dodając, że nie praca w uczelni jest dla niej sensem, ale samo uprawianie nauki.

W tym miejscu warto postawić pytanie, jakie wzorce zachowań będa typowe dla tych młodych ludzi, jeżeli pozostana oni w nauce, w akademii?

25 Podobne postawy można zidentyfikować w badaniach przeprowadzonych przez doktorantów. Zob. Towarzystwo Doktorantów Uniwersytetu Jagiellońskiego. Zespół ds. Jakości Kształcenia. Studia doktoranckie na Uniwersytecie Jagiellońskim, www.doktoranci.uj.edu. $\mathrm{pl} / \mathrm{c} /$ dokument (dostęp 12.11.2014). 
Druga wątpliwość, która muszę zaznaczyć, dotyczy nabywanych, przynajmniej w założeniach KRK (Krajowych Ram Kwalifikacji), kompetencji społecznych, bowiem zidentyfikowane badawczo relacje między doktorantami moga budzić zaniepokojenie.

Po czwarte, powracając do głównego nurtu moich rozważań należy dodać, że dochodzenie do wprawy badawczej w toku terminowania u mistrza buduje fundament dla przekonań o swojej fachowości. Richard Sennett badając stosunki pracy, ujął to zagadnienie jednoznacznie, „że gdy ludzie naucza się robić to, co robią naprawdę dobrze, zaczynają w pełni odczuwać swa pracę, staja się też zdolni do dogłębnego jej przemyślenia. Na tym właśnie poziomie ogromna rolę zaczynaja odgrywać problemy etyczne fachowości"26. Poczucie własnej adekwatności, bo o nim jest tu mowa, to długotrwała droga budowania siebie i odczytywania wszelkich kontekstów epistemologicznych, ontologicznych poznawanych bytów oraz kontekstu społecznego uprawiania nauki. Kryzys w poczuciu wspólnotowości z innymi uczestnikami studiów doktoranckich jest modalnościa tego zjawiska, w którym młody człowiek musi siebie na nowo zdefiniować i podjać decyzję, czy i jak będzie uprawiał naukę. Trudność tej decyzji pogłębia status doktoranta.

\section{Doktoranci pomiędzy akademickością a uzawodowieniem}

W tym miejscu koncentruje swój namysł wokół pytania, jakie mamy współczesne podejście do rozwoju naukowego młodych uczonych kształconych w ramach studiów doktoranckich? Odpowiedź zawarta jest w kategoriach pojęciowych opisujacych role pełnione w świecie akademickim. Pozornie oczywiste określenie „kadra naukowa, pracownik nauki” i „rozwój naukowy”, może być synonimiczne do „młody uczony” i „dojrzewanie młodego uczonego”. Tak jednak nie jest, bowiem sensy zawarte w tych kategoriach pojęciowych istotnie się różnią. Mówiąc wprost, dziśs mamy odmienne etykietowanie ról, które jednocześnie inaczej porządkuje kulturę wewnętrzna instytucji nauki. Uczony to ktoś zajmujacy się nauka, osoba zaangażowana głównie w jej rozwój zgodnie $z$ akademickimi kanonami etosowymi. Natomiast w pojęciu „kadra naukowa”, „pracownik

26 R. Sennett, Etyka dobrej roboty..., s. 33 
nauki" mamy akcent położony na zawodową funkcję i usytuowanie w jakiejś instytucji świadczącej usługi naukowe.

Określenie „młody pracownik nauki”, choć ustawy tego nie precyzuja, ma jednak swoje zastosowanie w kilku przepisach i w adresowaniu konkursów o granty naukowe. W domyśle i zwyczajowo rozumie się w tym znaczeniu osobę uprawiajaca naukę oraz realizująca zadania dydaktyczne w jednostce naukowej lub naukowo-dydaktycznej, jednak bez samodzielności naukowej. Znacznie większe sa problemy z zakwalifikowaniem do tej grupy uczestników studiów doktoranckich. Jeszcze nie tak dawno nie było widomo, jaki status przyznać tym młodym ludziom. Nie byli i nie są nadal zaliczani do pracowników naukowych, choć spełniaja powyższe kryteria, a wypełniając zadania dydaktyczne i naukowe, bliżsi byli statusowi uczonego niż studenta. Owo zaniedbanie legislacyjne trwało do 2005 roku, choć i bieżace regulacje w ustawie z 2011 roku i kolejnych $z$ lat 2013 i $2015^{27}$ nie rozstrzygnęły jednoznacznie tych dylematów. Nadal bowiem uczestnik studiów doktoranckich nie jest zakwalifikowany do którejś z grup. Podobnie jak studenci, doktoranci maja swoja reprezentację w samorządzie oraz ogólnopolską reprezentację zwaną Krajową Reprezentacją Doktorantów. Jako studenci mają legitymację i świadczenia stypendialne, uczestnicza w zajęciach dydaktycznych, a jako doktoranci pracownicy nauki prowadzą badania, przygotowując się do samodzielności naukowej, aplikują o granty badawcze oraz realizuja zajęcia dydaktyczne w ramach praktyki zawodowej. Można się domyślać, że dynamiczny wzrost liczby doktorantów w 2014 roku do ponad 42 tys. ${ }^{28}$ skutecznie blokuje szanse na zmiany w tym zakresie.

Każde badanie jest naznaczone indywidualna interpretacją badacza, tak i w tym przypadku nie zrezygnuje $z$ tego przywileju. W moim przekonaniu uczestnik studiów doktoranckich jest młodym uczonym i tego statusu nie może go pozbawiać fakt instytucjonalnej i systemowej organizacji jego dojrzewania naukowego. Bycie uczonym może oferować młodym ludziom etosowa kultura akademicka, nasza dobra (sic!) uniwersytecka tradycja. W tej sytuacji dla pełnej jasności dodam, że młodym pracownikiem nauki w moim rozumieniu jest każda osoba zaangażowana w rozwój

\footnotetext{
27 DzU z 2014 r., poz. 1198.

28 Zob. A. Kraśniewski, M. Próchnicka, op.cit.
} 
nauki (wszak doktorat ma wnosić znaczące osiagnięcie naukowe) oraz prowadzaca zajęcia dydaktyczne w instytucji naukowej i naukowo-dydaktycznej, nieposiadająca samodzielności naukowej (tę formalnie legitymizuje habilitacja i tytuł profesora).

Jeżeli rzecz dotyczy istotnej modyfikacji celów pracy uczonych, którzy stają się pracownikami nauki, wykonujacymi usługi eksperckie i edukacyjne, o czym wspomniałam wcześniej, to jest oczywiste, że sposób ich aktywności również musi ulec transformacji, a instytucjonalne (legislacyjne) reguły pociagaja za soba przemiany w generowaniu młodych pokoleń uczonych. W ustawach o szkolnictwie wyższym są ujęte zobowiązania skierowane wobec kadry akademickiej oraz doktoranta. „Usługa” kształcenia doktorantów powinna odbywać się w ramach określonej liczby godzin, za które samodzielni pracownicy uczelni otrzymuja wynagrodzenie. Rekrutacja doktorantów, kiedyś odbywająca się na zasadzie umowy między adeptem nauki i jego opiekunem naukowym, dziś odbywa się kolegialnie według instytucjonalnie ustalonych kryteriów, a wyniki jej sa jawne. Obok obowiązku odbywania zajęć, praktyk zawodowych i prowadzenia badań, z których składane jest coroczne sprawozdanie, ustawodawca dał prawo doktorantom do korzystania $z$ czasu wolnego od zajęć w wymiarze nieprzekraczającym ośmiu tygodni, co wskazuje na możliwość włączenia doktoranta do zadań wynikających z funkcjonowania instytucji. Regulacje ustawowe drobiazgowo odnosza się do stypendiów przyznawanych doktorantom, normalizuja też kwestie efektów kształcenia i warunków ich uzyskiwania, zajęć fakultatywnych, punktów ECTS, a wszystko to dla „zapewnienia najwyższej jakości kształcenia, prowadzącego do uzyskania kwalifikacji trzeciego stopnia" ${ }^{29}$. Wszystkie tu wskazane wytyczne oparte sa na ustaleniach międzynarodowych dotyczacych wdrażania systemu bolońskiego, o czym szerzej pisała Maria Czerepaniak-Walczak ${ }^{30}$.

Jak wobec tego jest realizowany proces kształcenia na studiach trzeciego stopnia, ile w nim jest teorii (aspektów akademickiego uprawiania nauki), a ile porusza się zagadnień przygotowujących do świadczenia przez doktorantów usług społeczeństwu (zawodowego przygotowania do uprawiania nauki poza strukturami akademickimi)?

\footnotetext{
29 Ibidem.

30 M. Czerepaniak-Walczak, op.cit.
} 
Prawo prowadzenia studiów doktoranckich, przypomnę, maja jednostki naukowe $z$ pełnymi uprawnieniami akademickimi oraz majace prawo do nadawania stopnia doktora w dwóch dziedzinach. W akademickim środowisku pedagogów prawo doktoryzowania aktualnie maja 24 jednostki naukowe, natomiast prowadzić studia doktoranckie może $16^{31}$ (w tym roku akademickim takie uprawnienia uzyskał Uniwersytet Zielonogórski, jednak jeszcze nie uruchomił studiów doktoranckich).

Próba poddania szczegółowej interpretacji realizowanych treści jest niezwykle skomplikowana, bowiem dostępność do sylabusów nie jest pełna, a ramowe programy studiów nie oddaja istoty kształcenia. Poddałam analizie tylko jedenaście ramowych programów, natomiast pięć dostępnych zestawów sylabusów dopełniało tylko mój ogląd. Nadto dodam, że sięgnęłam do 56 programów ramowych studiów doktoranckich $z$ innych dyscyplin, podejmując próbę porównania ich $z$ oferta pedagogów. W moich interpretacjach istotne było również identyfikowanie innych kompetencji (poza zaawansowana wiedza przedmiotowa i metodologiczna) kształtowanych w trakcie studiów trzeciego stopnia.

Należy podkreślić, że nie wszystkie jednostki naukowe umieszczają w otwartym dostępie dokumenty opisujące zawartość merytoryczna prowadzonych zajęć, co może budzić zdziwienie, bowiem świadomy swoich potrzeb przyszły doktorant może właśnie w nich poszukiwać motywów wyboru studiów. Drugim kłopotem była różnorodność kompozycji, nazewnictwo przedmiotów uwzględnianych w toku kształcenia. Można jednak dokonać choćby wstępnych ustaleń, porząlkujac realizowane przedmioty w moduły kształcenia.

Wnioski badawcze:

1. Różnice, które się pojawiły dotyczyły liczby punktów ECTS, wystapiła duża rozpiętość od 42 pkt ECTS na kierunku psychologia na Uniwersytecie Marii Curie-Skłodowskiej do 60 pkt ECTS na socjologii na Uniwersytecie Warszawskim. Pedagodzy we wszystkich dostępnych programach deklarują liczbę punktów ECTS pomiędzy 40 (np. Uniwersytet Gdański ) a 59 (Uniwersytet im. Adama Mickiewicza w Poznaniu).

2. Ogólnie wszystkie programy uwzględniaja moduł dydaktyki szkoły wyższej, co jest zgodne $z$ wytycznymi, jednak istnieją stosunkowo duże

${ }^{31} \mathrm{Na}$ podstawie Bazy OPI, https://polon.nauka.gov.pl/opi/aa/ck/stnauk/upr? execution=e3s 1 (dostęp 12.10.2014). 
różnice w przeznaczanej liczbie godzin. Rozpiętość jest dość znaczna - od 10 do 150 godzin, co musi budzić zastanowienie. W pierwszym przypadku może świadczyć o niedoborze wiedzy o akademickim kształceniu, natomiast w drugim o jej nadmiarze. To, czy tworzacy te programy studiów rzeczywiście mieli spójna filozofię przygotowania do prowadzenia zajęć, budzi poważną wątpliwość. Brak w obydwóch przypadkach dostępności do sylabusów uniemożliwia udzielenie odpowiedzi na to pytanie. Warto jednocześnie zaznaczyć, że tylko w trzech przypadkach uwzględniono elementy andragogiki i psychologii. Kompetencje nauczyciela akademickiego, czy też osoby prowadzacej szkolenia, którą może w przyszłości być absolwent studiów doktoranckich, wymagaja choćby podstawowej wiedzy w tych zakresach. Być może warto, zwłaszcza na wydziałach pedagogicznych, gdzie dysponuje się odpowiednią kadra, pomyśleć o pełnych uprawnieniach nauczycielskich. Ten pomysł zapewne można wdrożyć i na innych kierunkach $z$ myślą o rozszerzeniu uprawnień zawodowych doktorów. Dodam jednocześnie, że edukacja boryka się z deficytem kadry technicznej, co może być pewną oferta pracy dla młodych doktorów studiów technicznych, bo i w tych zawodach rynek pracy się kurczy.

3. Moduł akademickich praktyk zawodowych - zasadniczo wszędzie przewidziane są możliwości samodzielnego odbywania zajęć ze studentami. Okazuje się, że na kilku uczelniach doktorant samodzielnie prowadzi zajęcia dopiero na trzecim roku studiów.

4. Moduł metodologiczny ogólnie jest rozbudowany i obejmuje w większości programów zarówno badania ilościowe, jak i jakościowe, często do wyboru studenta. Liczba godzin przeznaczonych na jego realizacje wynosi od 75 do 180 godzin. W pierwszym przypadku prawdopodobnie metodologiczne przygotowanie zostało scedowane na seminarium i pracę nad własnym projektem, natomiast $\mathrm{w}$ drugim można zidentyfikować chęć wszechstronnego przygotowania metodologicznego, wyposażając młodego badacza w możliwie najszerszy wachlarz kompetencji.

5. Moduł ogólnoakademicki - w nim zostały zawarte przedmioty do wyboru, często $z$ oferty wydziałowej czy ogólnouczelnianej. W nim jednak część jednostek planuje kurs psychologii, filozofii edukacji bądź filozofii nauki, co wskazuje na przygotowywanie młodych uczonych do poruszania się, jeżeli zajdzie taka potrzeba, pomiędzy dyscyplinami. 
6. Moduł przeznaczony na dyscyplinę podstawową zajmuje od 45 do 150 godzin, co już wskazuje na wyraźne różnice w ugruntowaniu teoretycznym przyszłych uczonych bądź tylko na dopełnienie wiedzy pedagogicznej. To zróżnicowanie jest dość istotne, bowiem zawiera się w nim filozofia zaprojektowanych studiów doktoranckich. Oczywiście mogły i inne czynniki spowodować takie podejście, jak na przykład duża liczba doktorantów, którzy sa absolwentami niepedagogicznych studiów, ale częściej w takich przypadkach sa oni zobligowani do samodzielnego uzupełnienia wiedzy i zdania stosownych egzaminów.

7. Seminarium doktoranckie - od 6 do 30 godzin na semestr. Przyznam, że nie rozumiem tych rozbieżności, nie potrafię ich zinterpretować merytorycznie. Czyżby w uczelniach, gdzie jest tak mała liczba godzin do dyspozycji opiekuna naukowego zamiast płacić pracownikom, odwołuje się do etosu uczonego, który i tak, jak sądzę, pracuje ze swoimi podopiecznymi, nie liczac godzin kontaktowych. Analizując siatki studiów, spotkałam się $z$ interesujaca propozycja prowadzenia przez kolejnych promotorów otwartych seminariów dla wszystkich uczestników (domyślam się, że danego roku, choć to już nie było podane). Trzecią forma, która się pojawiła w kilku ośrodkach, było otwarte seminarium wraz z prezentacją własnej pracy naukowej przez doktorantów.

8. W programach można również zidentyfikować pojedyncze inicjatywy, które nie były zajęciami fakultatywnymi: przygotowujące do aplikacji w konkursach o granty; pisarstwa naukowego, również w języku obcym; kurs prawa autorskiego; etyczne aspekty pracy naukowej; emisji głosu; e-learningu, znajomości prawa własności intelektualnej, zarzadzania zespołem badawczym, planowania i zarządzania funduszami projektowymi.

W oparciu o ten skromny materiał badawczy, tu tylko ogólnie zasygnalizowany, można skonkludować, że z ramowych programów wyłania się jednoznaczne skoncentrowanie się na wykonaniu zadania w postaci wykształcenia badacza, uczonego i nauczyciela akademickiego. Rzadko planuje się, przynajmniej na poziomie programu, rozszerzenie oferty o inne kompetencje, poza zdefiniowanymi w przepisach nadrzędnych. Jednak już na tym poziomie ogólności można wyłonić spore różnice w filozofii kształcenia doktorantów. Pokuszę się o stwierdzenie, że mamy rozpiętość od tworzenia warunków dla osiągnięcia doktoratu jako celu (najsilniej 
reprezentowane), przez troskę o przygotowanie eksperckie do prowadzenia badań terenowych, po kreowanie warunków dla rozwoju uczonego (to odbywa się na indywidualnych seminariach i wynika $z$ tradycyjnego pojmowania akademickich powinności).

Interpretowanie i konsumowanie efektów nauki przez szeroko pojmowana praktykę wymaga od uczonych nieco innego wachlarza kompetencji, co powinno być uwzględnione w toku kształcenia młodej kadry. Już w 2006 roku sekretarz generalny KRASP prof. Andrzej Kraśniewski na posiedzeniu Rady Głównej Szkolnictwa Wyższego stwierdził, że wprowadzenie Strategii Lizbońskiej uruchomi ogromne środki na badania, które osiagna w 2010 roku 3\% PKB, „a na rynku pracy pojawi się 700 tys. nowych miejsc pracy zwiąanych $z$ badaniami naukowymi, ale jedynie $10 \%$ z nich w uczelniach". Dalej stwierdził, że w Polsce - na 6 tys. doktorów rocznie kończacych studia, uczelnie sa w stanie zaabsorbować jedynie kilkaset osób ${ }^{32}$. Choć obecnie sytuacja nie uległa pozytywnym zmianom, to polityka rzadu jest konsekwentna i klarowna, chodzi o zwiększenie „wydajności” studiów doktoranckich i, jak stwierdziła obecna Minister Nauki i Szkolnictwa Wyższego prof. Lena Kolarska-Bobińska, inaugurujac szeroka kampanię „Zawód Naukowiec”: „Przewiduje się, że w roku 2020 Unia Europejska będzie potrzebować około miliona naukowców"33. Nie mnie dyskutować z tymi prognozami, choć na marginesie warto zasygnalizować pewną wątpliwość, bowiem okazuje się, że problemy z zatrudnieniem na uczelniach i poza nimi maja młodzi doktorzy w wielu krajach europejskich, nawet tak rozwiniętych jak Niemcy, a zarobki i formy umów budzą zdecydowany sprzeciw sfrustrowanego środowiska ${ }^{34}$. Minister Nauki i Szkolnictwa Wyższego przekonuje jednak, że absolwenci studiów doktoranckich maja przed soba misję podniesienia jakości badań w kraju, rozwoju gospodarczego będącej w kryzysie ekonomicznym Europy, obiecując jednocześnie, że zarobki w nauce będa coraz atrakcyjniejsze $\mathrm{e}^{35}$.

\footnotetext{
${ }^{32}$ M. Molasy, Standardy dla doktorantów, „Forum Akademickie” 2006, nr 7-8, https:// forumakademickie.pl/fa/2006/07-08/standardy-dla-doktorantow/ (dostęp 10.10.2015).

${ }_{33}$ Ruszyła kampania Zawód Naukowiec, www.nauka.gov.pl/aktualnosci-ministerstwo/ ruszyla-kampania-zawod-naukowiec.html (dostęp 10.10. 2015).

34 Prekariat mit Doktorgrad, www.zeit.de/2015/06/wissenschaftler-petition-arbeitsbedingungen (dostęp 10.10.2015).

${ }^{35}$ Ruszyła kampania...
} 
Wobec tych stwierdzeń należy sformułować pytanie, jakiego odczytania siebie, swoich powinności wobec nauki i wspólnoty uczonych oraz jakiej wprawy w uprawianiu nauki może dostarczyć instytucjonalne kształcenie doktorantów? Na to pytanie również odpowiedział prof. Kraśniewski, stwierdzając, że:

Rynek pracy w gospodarce zgłasza natomiast nowe oczekiwania wobec absolwenta studiów III stopnia, takie jak: umiejętności uczenia się, komunikowania się ze specjalistami, z mediami, zarządzania projektami, zespołami badawczymi, elastyczność czy przedsiębiorczość. W Europie coraz częściej zdarzają się przypadki, że uczelnie kształca doktorantów wspólnie $z$ przedsiębiorstwami i to tam się odbywa większość praktycznych zajęć oraz badañ ${ }^{36}$.

Dalej dodając, że kształcenie doktorantów należy rozszerzyć, czyli zwiększyć ich liczbę, jednak szczególnie w dyscyplinach, w których jest odczuwane niskie nasycenie.

Przytaczając głosy uczonych skupionych w jednym $z$ głównych ciał reprezentujacych środowisko akademickie, ukazałam rzecz o kapitalnym znaczeniu. Otóż dotykam tu zjawiska, które Barbara Tuchańska zdefiniowała jako „przekształcania naukowych stosunków społecznych”37. $Z$ jednej strony mowa o kwestii zmian wewnatrz akademii, choćby przez zmiany/instytucjonalizacje kariery naukowej, natomiast $z$ drugiej strony o przemianach wewnątrz nauki. Wspomnę również o głośnym manifeście Lyotarda, w którym ten skrajnie lewicowy uczony ostro zaatakował tradycyjne ujęcie sensów pracy uczonych, wskazał na publiczne ich zobowiazanie do zaspokajania nie tylko własnych ( $z$ wnętrza akademii) interesów poznawczych, ale respektowanie interesu publicznego. W pierwszym znaczeniu prawda była prawdą uczonych, w drugim ma się stać własnością społeczna. „Nauka gra swoją własną grę”, czyli uczeni maja własna tajemna zabawę, hermetyczną dla ludu, a jemu maja służyć, bo od niego otrzymuja środki na jej realizację ${ }^{38}$. Obszerność zagadnienia nie pozwala na jego rozwinięcie, natomiast ważna jest konkluzja dotycząca zarzutu, że społeczność uczonych skoncentrowana na budowaniu teo-

36 M. Molasy, op.cit.

37 B. Tuchańska, Rozwój poznania jako proces społeczny, PWN, Warszawa 1982, s. 305.

38 J.-F. Lyotard, Kondycja ponowoczesna, tłum. M. Kowalska, J. Migasiński, Fundacja Aletheia, Warszawa 1997, s. 108. 
rii potwierdzała swoją odrębność i uwiarygodniała potrzebę swojego istnienia. Mówiąc wprost, to społeczne zapotrzebowanie na teorię tworzyło grunt, uzasadnienie dla bytu akademickiego, który przez swoja specyficzna organizację i stworzona odrębność zapewniał pokoleniowe trwanie tej dziedziny kultury. Nauka w tradycyjnym ujęciu powinna spełniać kanony teoretyczności, wręcz stroniąc od wymiarów pragmatycznych, natomiast współczesny świat dopomina się zastosowań. Na marginesie dodam, że jest to najgłębsza szczelina, a krytyczność jej ukazuja fakty zamykania nierentownych kierunków kształcenia w naukach podstawowych, głównie humanistycznych, oraz części nauk społecznych ${ }^{39}$. Nie można jednak nie dostrzegać rosnacej wraz z liczba doktorantów trudności w wypełnianiu powinności akademickich. Poczucie zagrożenia samodzielnych pracowników nauki wywoływane powiększająca się liczba młodych doktorów, z jednoczesną świadomością ich zróżnicowanego potencjału, rodzi reakcje obronne. Mamy do czynienia ze zjawiskiem podniesienia wykształcenia całego społeczeństwa i nie ma od tego odwrotu. Kiedyś tytuł magistra/inżyniera był finalny, a dziś osoby z podobnymi ambicjami i możliwościami intelektualnymi sięgaja po doktorat. „Wyścig między edukacją i technologia”" zmusza systemy kształcenia do szybkiego reagowania, tworzenia nowych dostępności do kwalifikacji ${ }^{40}$. Studia doktoranckie daja szansę tym najzdolniejszym, a problem tkwi w tym, czy sposób kształcenia ich jest adekwatny do potrzeb społecznych. Brak zróżnicowania studiów doktoranckich, nastawienia na tradycyjne uprawianie nauki, brak w polskim systemie oferty doktoratów zawodowych rodzi dylematy, o których pisałam powyżej, związane $z$ jednej strony $z$ obrona jakości uprawiania nauki i własnej pozycji samodzielnej kadry naukowej, zaś z drugiej koniecznościa zwiększania liczby doktorantów, których jakość, co oczywiste, istotnie się różni. W tej najpoważniejszej szczelinie, w której tkwia doktoranci i cała akademicka społeczność, każda $z$ grup uczonych ma zgoła inne oczekiwania, lęki i interesy. Doktoranci, wszak oni mnie tu najbardziej interesują, marzą o życiu w akademii

39 A. Krzemińska, Filozoficzny węzeł gordyjski, „Gazeta Wyborcza” z 14.01.2014 r; List otwarty kulturoznawców i badaczy kultury do Minister Nauki i Szkolnictwa Wyższego prof. dr hab. Leny Kolarskiej-Bobińskiej, http://wyborcza.pl/1,95892,15472249,List_otwarty_ naukowcow_do_minister_nauki_i_szkolnictwa.html (dostęp 10.10.2015).

40 T. Piketty, Kapitał $w$ XX wieku, tłum. A. Bilik, Wydawnictwo Krytyki Politycznej, Warszawa 2015, s. 375, 600-604 i in. 
(w tym tradycyjnym, czystym wymiarze), od wspólnoty uczonych oczekują etosowych postaw, bo też nadal tym nasiaknnięte sa struktury społecznego myślenia i programy ich kształcenia. Samodzielni pracownicy nauki wypełniając swoją tradycyjna powinność (zakładam, że w większości to czynia, choć na tym polu dostrzegamy pęknięcia), czują zagrożenie dla nauki i siebie. Rozwiązaniem $z$ tego dylematu, w moim przekonaniu, jest rozbudowanie oferty ścieżek rozwoju naukowego i zróżnicowanie na doktoraty zawodowe i naukowe (wszak mamy studia wyższe oparte na tej logice). „Wyścig między edukacją i technologia” obliguje nas do zajęcia się tym problemem, bowiem brak jego rozwiazania będzie skutkować zasygnalizowanymi tu zjawiskami. Powrócę do głosów w dyskusji prowadzonej w ramach posiedzenia Rady Głównej i przywołam wypowiedź prof. Pawlikowskiego, który odniósł się do szeroko dyskutowanych Europejskich Ram Kwalifikacji. Absolwent studiów trzeciego stopnia powinien zostać wyposażony w specjalistyczną wiedzę, pozwalająca na analizę i syntezę, oraz ocenę nowych i złożonych idei; opanować umiejętności metodologiczne konieczne dla prowadzenia badań. Osobowo należy go również doskonalić pod katem kształtowania „kompetencji i predyspozycji, m.in. w zakresie samodzielności, odpowiedzialności, zdolności uczenia się i komunikatywności"41. Wymienione cechy absolwentów studiów doktoranckich odpowiadaja tym, które sa preferowane w korporacjach, na co również wskazuje Sennett ${ }^{42}$, dodaje jednak niezwykle istotny komponent kompletnie pominięty - „rozumienie samego siebie” przy zwróceniu uwagi na potrzebę samoidentyfikacji zawodowej oraz przynależności społecznej do określonej grupy zawodowej ${ }^{43}$. W swoich badaniach również zajęłam się tym istotnym aspektem, przeprowadzajacc rozmowy badawcze $\mathrm{w}$ trakcie prowadzenia zajęć na studiach doktoranckich w swojej macierzystej jednostce, w uczelni technicznej na Wydziale Architektury i Budownictwa oraz w trakcie wielu konferencji naukowych. W sumie odbytych rozmów było 34, zatem nie sa to badania w żadnej mierze reprezentatywne, choć uzyskałam jednoznaczne deklaracje chęci uprawiania nauki w strukturach akademickich, mimo niskich zarobków w akademii i wcześniejszych doświadczeń zawodowych oraz badawczych realizowanych dla in-

\footnotetext{
41 Ibidem.

42 R. Sennett, Etyka dobrej roboty..., s. 297-325.

${ }^{43}$ R. Sennett, Kultura nowego kapitalizmu..., s. 59.
} 
nych podmiotów. Podkreślam, że nie były to deklaracje naiwne, bowiem doktoranci mieli już wiedzę o trudnościach wynikających z ubiegania się o środki na projekty badawcze, część z nich realizowała własne projekty, to jednak bycie uczonym w tradycyjnym rozumieniu było dla nich celem, a może tylko marzeniem o stabilności, która tradycja obiecuje. Niezwykle cennym doświadczeniem badawczym był mój udział na zaproszenie działaczki ruchu Obywateli Nauki w roli doradczej przy opracowywaniu Paktu dla Nauki, części dotyczącej „Doktorantów. Studiów doktoranckich”. Młodzi pracownicy nauki tworzac swoja propozycję, wnosili głównie postulaty dotyczace poprawy jakości pracy dydaktycznej i efektywniejszego właczania młodziė̇y akademickiej w projekty badawcze, zwiększenia zajęć podnoszacych kompetencje lingwistyczne, przygotowania do aplikowania o granty naukowe czy wreszcie włączania zadaniowego w struktury zakładów naukowych i katedr promotorów. Muszę przyznać, że zaskoczył mnie początkowy brak szerszego spojrzenia na kwestie przygotowania zawodowego, co odczytuję jako jednoznaczne lokowania swojej przyszłości zawodowej w strukturach nauki. Podobnie można zinterpretować wyniki badań przeprowadzonych wśród doktorantów w Uniwersytecie Jagiellońskim $^{44}$. Trudno jest jednoznacznie wskazać powód takich planów życiowych, tym bardziej, że niewielu $z$ nich, jak wykazałam powyżej, faktycznie będzie kontynuowało swój rozwój zawodowy w uczelni wyższej. Można jednak przypuszczać, że znaczący był fakt choćby częściowej przynależności do świata nauki. Drugim być może jest właśnie zajmowanie się nauka w innych wymiarach, na najwyższym poziomie, co niezwykle rozwija i rozbudza „apetyt” intelektualny. Tu mam dylemat, jeżeli te hipotezy sa prawdziwe, to doktoranci znajdujacy się w tej szczelinie akademickości dostali przedsmak „uczty intelektualnej”, „pierwsze danie”, jednak „drugie i deser” moga być poza zasięgiem ich możliwości. Z drugiej jednak strony to właśnie najwyższy kunszt mistrzostwa opiekunów naukowych, kadry nauczajacej, może doprowadzić do takiego efektu, co musi budzić zadowolenie. Mimo dość pesymistycznego wydźwięku całego artykułu widzę pozytywny/optymistyczny aspekt tradycyjnej, etosowej pracy z młodymi adeptami nauki i wysoce wykształcona kadra innych sektorów.

${ }^{44}$ K. Keler, E. Krzaklewska, Studia doktoranckie na Uniwersytecie Jagiellońskim. Głos doktorantów, Wydawnictwo Towarzystwo Doktorantów Uniwersytetu Jagiellońskiego, Zespół ds. Jakości Kształcenia, Kraków 2009, www.doktoranci.uj.edu.pl/c/document_library/get_file?uuid (dostęp 10.10.2012). 


\section{Kto dziś czuwa nad akademickością, a kto nią zarządza? Zamiast zakończenia}

„Władza produkuje wiedzę" - stwierdzeniem Foucaulta ${ }^{45}$ właściwie można by zakończyć prowadzone tu rozważania. Powracając jednak do metafory szczeliny, przypomnę, że pojawia się ona na skutek różnych czynników, w geografii wskazuje się na egzogenne i endogenne, a efekty ich działania sa nieodwracalne. W przestrzeni akademickiej po 2005 roku nastapiło „trzęsienie ziemi”, którego skutki coraz lepiej dostrzegamy i rozumiemy. Każda z kolejnych ustaw dotyczących nauki i szkolnictwa wyższego wprowadzając kolejne regulacje, uzmysławia logikę władzy ${ }^{46}$. Stopniowo pojawiajace się „rysy”, wcześniej zbagatelizowane i potraktowane jako drobne pęknięcia, przez część uczonych zostały odebrane jako sprzyjające okoliczności do realizacji własnych celów badawczych - głównie w naukach stosowanych, niosły rekonstrukcję akademickości, nauki i samych uczonych. Hans Georg Gadamer wyraził pogląd doskonale opisujący kruchość akademickości:

[...] Również człowiek teorii, życia oddanego czystemu poznaniu, jest zależny od sytuacji społecznej oraz politycznej praktyki. [...] Byłoby urojeniem mniemać, iż życie poświęcone teorii jest niezależne od życia politycznego i społecznego wraz z jego uwarunkowaniami ${ }^{47}$.

Napór ekonomicznej rzeczywistości wypiera tradycyjna akademickość, a powinności w nia wpisane zostaja zastępowane wartościami utylitarnymi i zewnętrznymi regulacjami biurokratycznymi. W watpliwości te wpisuje się pogląd Małgorzaty Czarnockiej, która dostrzega również wielowymiarowość tego zjawiska i stwierdza, że „podmiot poznania" w kartezjańskim rozumieniu, zawieszający wpływy zewnętrzne, oddany w swojej wielkiej, twórczej samotności prawdzie nauki, nie jest impregnowany na potrzeby społeczne, jest tylko „idealnym podmiotem

45 M. Foucault, Nadzorować i karać, Aletheia, Warszawa 2009, s. 104.

46 Ustawa Prawo o Szkolnictwie Wyższym, DzU z 2005 r., nr 164, poz. 1365 (tekst jedn.). Opracowano na podstawie: DzU z 2012 r., poz. 572, 742, 1544; DzU z 2013 r., poz. 675, 829, 1005, 1588, 1650; DzU z 2014 r., poz. 7, 768, 821, 1004, 1146, 1198, http://isip. sejm.gov.pl/DetailsServlet?id=WDU20051641365 (dostęp 8.02.2015).

47 H.-G. Gadamer, Prawda i metoda, przekład B. Baran, Wydawnictwo Inter esse, Kraków 1992, s. 9. 
poznania”48. Dopełnia tę myśl stwierdzeniem, że „człowiek rozpościera się między swoja prywatnością a społeczna rzeczywistością zewnętrzna”, jednak nigdy nie jest ostatecznie zdeterminowany, „nie jest pionkiem w grze”, „mimo społecznej presji, która kształtuje procedury poznawcze i treściowe fundamenty poznania"49. Autorka tych myśli zbliża się do poglądów Flecka i współczesnych poststrukturalistów czy pragmatystów, twierdząc, że $\mathrm{w}$ indywidualnym podmiocie poznania dokonuje się połączenie własnego planu życiowego $z$ planem zbiorowym, co powoduje, że na poziomie świadomości i nieświadomości moga się one przeplatać, stając się osobistymi sensami, schematami myślenia, w czym ujawnia się społeczny charakter tworzenia wiedzy. „Jego fundamenty zakodowane sa w indywidualnym podmiocie przez społeczne wkodowanie (...)", przez język, schematy konceptualizowania i wykorzystania wiedzy ${ }^{50}$. Autorka tych słów pozostawia decyzję samym uczonym, których tożsamość społeczna oraz podmiotowe wybory będą kanwą dla dalszych poczynań. Jakie decyzje będa podejmowali tak kształceni doktoranci? Ile w nich będzie etosowych zobowiązań? Kto będzie w przyszłości oczekiwał tych etosowych zobowiąań?

Słowa kluczowe: akademickość, doktorant, studia doktoranckie, programy ksztatcenia doktorantów

\section{DOCTORAL STUDENTS IN THE SPLITS OF THE ACADEMIC ETHOS}

\section{Summary}

The subject of the article concerns the situation of doctoral students trained in the context of an institutionalized system of higher education. The academic ethos has been offered for sale, and has become another educational service used for different interests. The metaphor of "gaps" that I introduce in the article describes well the unprivileged position of the young people entering the world of

48 M. Czarnocka, Podmiot poznania a nauka, Wydawnictwo Uniwersytetu Wrocławskiego, Wrocław 2003, s. 314-328.

49 Ibidem, s. 339.
50 Ibidem, s. 341. 
science. I try to identify the "gaps" and the "tensions" disintegrating the existing order, in which the traditional ethos of commitments is eroded by the new system of claims. The university tied up with formal regulations creates a new environment where everything: the role of mentors, the relationships, and the position of doctoral students change significantly. I choose hermeneutic to analyze the framework education programs, and to try to answer the question: What goals are implemented and what effects of the training of doctoral students emerge from the interpretation of the source material? I refer also to qualitative data (interviews with university students) which shows the evolution of the youth's attitudes to their own role and place in the world of scholars.

Keywords: academic ethos, doctoral student, PhD studies, doctoral study programs

Translated by Aleksandra Błachnio 